Yan Yuan,

post-graduate student, Department of Music and Choreography, South Ukrainian National Pedagogical University named after K. D. Ushynsky, 4, Fontanska Doroha Str., Odesa, Ukraine

\title{
CREATIVE ACTIVITY AS A METHOD OF ORGANIZING FUTURE MUSIC TEACHERS' SELF-PREPARATION FOR TEACHING PRACTICE
}

Methods and learning technologies used in the modern educational process direct future music teachers towards mastering the prepared information. Contradiction can be seen between the formal knowledge that many students have and their poor ability to study independently as well as their insufficient possession of the latest self-study methods. Creative activity during the learning process is considered to be the means of activating independence in studying, initiative and curiosity of musical students.

Keywords: creative activity, cognitive activity, musical students, self-study, teaching practice.

Socioeconomic changes that occured both in China and in Ukraine make the problem of future teachers' training relevant. Nowadays every modern human should possess skills required to operate in a situation where something needs to be chosen, make decisions (during lesson to be able to change the alleged plan, find interesting forms of creative work, cultivate in students active life position). V. Radionov, N. Radionova, M. Sokolova indicate that a modern teacher must possess significant professional abilities and skills, ability to think in a creative way by planning "individual itineraries of students" [5]. The basis of self-development and self-fulfilment, according to B. Porshnev, is creative approach.

The problem of creative development in the whole pedagogical process has been analyzed by the following researchers (F. V Andreyev, D. B Bogoiavlenska, I. I. Iliasov, Ya. A. Zaitseva, A. A Kirsanov, A. A Malakhov, R. A. Petrosova, O. G Sushchenko, A. Engelbrecht etc.); in the aesthetic education (N. Ye. Vorobyov, V. G Kuharonak, G. P. Novikov, Ye. Yu. Romanov, N. M. Sokolnikov, Ye. A. Solntseva, L. N. Shulpina, etc.); during cognitive independence development (L. G Vyatkin, Ye. I. Yeremin, G. I. Shchukin); through the development of students' creative potential in musical faculties in the system of higher education (N. L. Bila, O. L. Golovin, A. I. Kovalev, G. I. Shevchenko, T. I. Shevchenko, etc.).

Methods and learning technologies used in modern educational process direct future music teachers towards mastering the prepared information. Contradiction can be seen between the presence of formal knowledge that many students have and their poor ability to study independently as well as their insufficient possession of the latest self-study methods.

As one of the methods of activating independence, initiative and curiosity of musical students that needs to be mentioned, according to V. Arshavskiy, M. Dyachenko, G. Shchukin, is creative activity as a higher level of cognitive activity. The aim of this article is to define the basic mechanisms of creative activity's influence on the improvement of self-preparation approach of students for pedagogical practice. Implementation of this aim sets the following tasks:

- to prove the feasibility of creative activity manifestation as means of self-study for teaching practice;

- to describe the specific features of teaching practice as one of the learning activities of students at pedagogical universities;

- to identify the nature of creative activity in the context of educating music teachers at higher educational institutions;

- to consider the components of creative selfdevelopment of student's personality.

The methodological and theoretical basis of the study are the following components: education act, the national doctrine of education development in Ukraine in the twenty-first century; content theory and technologies of training for future teachers (V. Bezpalko, V. Bondar, S. Honcharenko, G. Kostiuk, S. Sysoieva etc.); psychological theory of personality manifestation while studying (A. Petrovskyi, K. Platonov, D. Bohoiavlenska etc.); principles of educational and cognitive organizational activity (I. Lerner, O. Savchenko, G. Shchukina, etc.); theory of music teacher training (L. Archazhnikova, N. Hrodzenska, H. Padalka, O. Rudnytska, O. Rostovskyi). The following mutually beneficial theoretical methods are used in the research: analyzing scientific and methodical literature, summarizing the results of theoretical conclusions and existing experience of individual's creative activity formation during the learning process; systematization of scientific and theoretical information, summarizing the results of mastering theoretical sources.

It is well-known that there is a fundamental meaning that cognitive activity has: the transfer of existent knowledge and creation of knowledge based on independent mental activity of students. The main type of cognitive activity of students in the context of existent knowledge transfer is memorizing, at low levels of activity and selfstudy. The skills and abilities of students to study independently are formed not by themselves, but as a result of specially organized tasks of creative manner, being or- 
ganically included in the educational process. In the process of music education, according to Ye. N. Mykheieva, creative development is associated with the "formation of three areas of the human mind" i.e. rational (intellectual and practical), emotional (motivational value) and volitional (moral and practical). Thus, the author of the thesis considers the very essence of music education in the context of human personality development through the expression of creative activity.

Thus, the rational field of the creative development of a future music teacher (rational component) is connected with his/her mastering systematic knowledge, abilities and skills combined with productive types of creative activity. Emotional sphere of creative activity (motivational value component) suggests, according Ye. N. Mykheieva, the craving of students to fulfil their creative achievements, cognitive needs and creative design. Volitional component (moral and practical) is associated with willingness of students to self-transformation, modelling different ways of musical activity.

The most creative activity can be shown by musical students during teaching practice which has the following tasks:

- educating students' interest in the music teaching profession;

- forming an integral view of educational activities;

- formation of pedagogical skills;

- creating experience in teaching activity.

Each student in addition to mastering the methodological guidelines, professional knowledge and abilities, vocal, instrumental and conducting skills has the opportunity to build his/her own concept of a music lesson, determine his/her position on the issue discussed using a variety of instructional techniques, develop creative tasks, be able to find independently solutions to problems that are related to discipline that is being taught, provide students with clear information, create an emotional climate in the classroom.

Thus, the purpose of teaching practice lies in consolidation and deepening the knowledge gained by students in learning process and also in acquiring organizational and creative experience based on person-oriented and projection-searching approaches. Accordingly, teaching practice performs a number of functions, including: adaptive, training, educative, developing, forming, diagnostic.

Based on pedagogical observation, it is possible to mention the main factors that prevent the manifestation of creative activity of students in the process of selfpreparation for teaching practice. Those are the following: uncertainty of a student, his/her commitment to study according to certain schemes, setting for the specified method of organization of educational process.

The conclusion of S. A. Abasov needs to be added to the above mentioned. He differentiates the negative factors in the following way: practitioner's and sub-faculty's fear of control, fear to make a mistake or be misunderstood, state of anxiety, focusing attention on themselves, their worries, interests [1].
Increasing the role of self-study in the preparation for future music teaching involves changing the position of teacher and student in the learning process. Changing the position of a teacher requires him/her to learn some new roles: a tutor, a consultant and moderator of the educational process (Ye. Balakirev, R. Bogdanov, A. Piskunov, A.Tryapitsina). Tutoring, according to the authors, is based on the following principles:

- the principle of support that is aimed at the development of students' self-sufficiency and independence in solving problems; grams;

- the principle of implementation of educational pro-

- the principle of development targeted at support of the students' personal development.

The activities of a teacher-tutor are not aimed at reproduction of information, but at work with the interests, experience, needs and aspirations of a student.

The essence of the so-called tutor-student model lies in the lack of traditional presentation of the material by a teacher that is further replaced with counselling. According to scientists, there are three functions of theory and practice of counselling: expertise, modelling and procedural. Modelling is aimed at developing potential abilities of a student. The basis of this approach lies in the necessity to identify hidden opportunities and unrealized skills of a student. In addition to that, one can make an agreement with students for self-studying paragraphs or parts of the course.

Based on the stated above, it is possible to make the following conclusions:

1. The main tasks of teaching practice of students are the following: educating motivation for self-improvement, formation of an integral view of educational activities, the creation of teaching experience, the formation of purpose for solving the tasks independently without any help.

2. Creative activity in the learning process is seen as a higher level of cognitive activity, characterized by the desire of an individual to overcome the usual rules and means of action. Creative activity develops students' willingness for self-improvement, to be independent and to show initiative while solving various educational and creative tasks.

3. The development of activity of a future music teacher in music education has undergone a number of stages: directive or reproductive-imitative (awakening the interest of students for teaching and creative activities); search and performing (raising awareness and importance of his/her creative productive activity); creative (active engagement into productive creative activity).

4. One of the most important conditions for improving the training of a highly qualified individual is to focus on creative development of a future music teacher. The decisive factor, if taken subjectively, is the creative self-development of a personality that has the following components:

- self-motivation, regulation, self-fulfilment; 
- self-organization by means of organizing knowledge, abilities and skills, experience of algorithmic and creative activity;

- self-education and self-study achieved through mastering pedagogical knowledge;

-the formation and development of creative competence;

- self-determination through initiation of situational, searching and overstandardized activity that provides creative self-realization in work and communication;

\section{ЛІТЕРАТУРА}

1. Абасов 3. А. Роль педагогической практики студентов в их профессиональном становлении / 3. А. Абасов. - СПб. : СГТУ, 1996. - 140 с.

2. Григорьева М. С. Метакогнивные процессы: их структура и роль в решении задач / М. С. Григорьева // Филологические науки: Вопросы теории и практики. - Тамбов: Грамота, 2014. - № 1. - Ч. 1. - С. 18-20.

3. Михеева Е. Н. Развитие творческой активности будущего учителя в процессе музыкального образования : автореф. дис. ... канд. пед. наук : спец. 13.00.01 / Е. Н. Михеева. - Архангельск, 2002. - 23 с.

4.Организация самостоятельной работы студентов по педагогическим дисциплинам : [уч.-метод. пособие для преподавателей высшей школы] / [Э. В. Балакирева, Р. У. Богданова, О. Б. Даутова и др.

\section{REFERENCES}

1. Abasov, Z. A. (1996). Rol pedagogicheskoy praktiki studentov $v$ ikh professionalnom stanovlenii [Role of teaching practice of students in their professional development]. Saint Petersburg : SGTU [in Russian].

2. Grigorieva, M. S. (2014). Metakognivnye protsessy: ikh struktura i rol $\mathrm{v}$ reshenii zadach [Metacognitive processes: their structure and role in problems solution]. Filologicheskie nauki: Voprosy teorii i praktiki - Philological sciences: Issues of theory and practice, 1, 18-20. Tambov: Gramota [in Russian].

3. Mikheeva, E. N. (2002). Razvitie tvorcheskoy aktivnosti budushchego uchitelya $\mathrm{v}$ protsesse muzykalnogo obrazovaniya [Development of artistic activity of a future teacher in the process of music education]. Extended abstract of Candidate's thesis. Arkhangelsk [in Russian].

4. Balakireva, E. V., Bogdanova, R. U., Dautova, O. B. (2009). Organizatsiya samostoyatelnoy raboty studentov po pedagogicheskim distsiplinam : uch.-metod. posobie dlya prepodavateley vysshey shkoly [Organization of independent work of students in pedagogical dis-
- self-control and self-correction carried out by means of problem and task analyzing, selection activity's criteria, self-evaluation of results. Analysis of samples of creative self-development of teachers' personality shows that the strategy of creative self-development is determined, on one hand, by the need for professional improvement and, on the other hand, by understanding and accepting their strong and weak professional and personal qualities.

; под ред. А. П. Тряпицыной]. - Спб. : РГПУ имени А. И. Герцена, 2009. - 123 с.

5.Радионов В. Е. Взаимодействие педагогов и старших школьников : технология и творчество / В. Е. Радионов. - Л. : РГПУ, 1989. - 84 с.

6.Соколова М. Л. Проектирование индивидуальных образовательных маршрутов студентов в вузе : автореф. дис. ... канд. пед. наук : спец. 13.00.01 / М. Л. Соколова. - Архангельск, 2001. - 23 с.

7.Шех Т. В. Личностно-ориентированный подход в обучении школьников иностранному языку [Электронный ресурс] / Т. В. Шех // Концепт: научнометодический электронный журнал официального сайта эвристических олимпиад.- 2 квартал 2011. - Киров.

ciplines: methodical guidebook for university teachers]. Tryapitsyna, A. P. (Ed.). Saint Petersburg: RGPU imeni A. I. Gertsena [in Russian].

5.Radionov, V. E. (1989). Vzaimodeystvie pedagogov $i$ starshykh shkolnikov: tekhnologiya i tvorchestvo [Interaction of teachers and senior school pupils: technology and creativity]. Leningrad: RGPU [in Russian].

6.Sokolova, M. L. (2001). Proektirovanie individualnykh obrazovatelnykh marshrutov studentov v vuze [Designing individual educational ways of students at a university]. Extended abstract of Candidate's thesis. Arkhangelsk [in Russian].

7.Shekh, T. V. (2011). Lichnostno-orientirovannyy podkhod $\mathrm{v}$ obuchenii shkolnikov inostrannomu yazyku [Personality-focused approach in teaching foreign languages to students]. Kontsept: nauchno-metodicheskiy elektronnyy zhurnal ofitsial'nogo sayta evristicheskikh olimpiad - Concept: scientific and methodical electronic journal of the official website of heuristic Olympiads. Kirov [in Russian].

\section{Янь Юань, \\ аспірант кафедри музичного навчання та хореографіï, Південноукраїнський національний педагогічний університет імені К. Д. Уиинського, вул. Фонтанська дорога, 4, м. Одеса, Украӥна}

\section{ТВОРЧА ДІЯЛЬНІСТЬ ЯК МЕТОД ОРГАНІЗАЦІЇ САМОПІДГОТОВКИ МАЙБУТНЬОГО ВЧИТЕЛЯ МУЗИКИ ДО ПЕДАГОГІЧНОӤ ПРАКТИКИ}

Методики і технології навчання, що використовуються в сучасному освітньому процесі, орієнтують майбутнього вчителя музики на засвоєння готової інформації. Фіксується протиріччя між наявністю формальних знань у студентів і слабким володінням останніми методами самопідготовки та самостійної роботи. Одним із 
методів активізації самостійності, ініціативи і допитливості студентів-музикантів виділяється творча активність як вищий рівень пізнавальної активності. У статті зазначається, що кожний студент, окрім оволодіння методичними рекомендаціями, професійними знаннями й уміннями, вокальними, інструментальними і диригентськими навичками, має можливість вибудовувати власну концепцію уроку, визначати свою позицію у розглянутому питанні, використовувати різноманітні методичні прийоми, розробляти творчі завдання, самостійно знаходити рішення проблем, пов'язаних із дисципліною, сприйняттям інформації учнями, створенням емоційного клімату на уроці. Таким чином, мета педагогічної практики - закріплення і поглиблення знань, отриманих студентами у процесі навчання, а також набуття досвіду організаційно-творчої роботи на основі індивідуально-орієнтованого і проекційно-пошукового підходів. Педагогічна практика виконує ряд функцій, серед яких: адаптаційна, навчальна, виховальна, розвивальна, формуюча, діагностична. На основі педагогічного спостереження автор статті робить висновок, що основними факторами, які заважають прояву творчої активності студентів у процесі самопідготовки до педагогічної практики, є непевність студента, прихильність до певних схем, установка на заданий спосіб організації навчально-виховного процесу. Однією з найважливіших умов вдосконалення професійної підготовки висококваліфікованих кадрів є «орієнтація на індивідуальний розвиток майбутнього вчителя». Вирішальним чинником суб'єктивного порядку може стати творчий саморозвиток особистості.

Ключові слова: творча діяльність, пізнавальна активність, студенти-музиканти, самопідготовка, педагогічна практика.

Янь Юань, Южноукраинский национальный педагогический университет имени К. Д. Ушинского, ул. Фонтанская дорога, 4, м. Одеса, Украина

\section{ТВОРЧЕСКАЯ ДЕЯТЕЛЬНОСТЬ КАК МЕТОД ОРГАНИЗАЦИИ САМОПОДГОТОВКИ БУДУЩЕГО УЧИТЕЛЯ МУЗЫКИ К ПЕДАГОГИЧЕСКОЙ ПРАКТИКЕ}

Методики и технологии обучения, используемые в современном образовательном процессе, ориентируют будущего учителя музыки на усвоение готовой информации. Фиксируется противоречие между наличием формальных знаний студентов и слабым владением последними методами самоподготовки и самостоятельной работы. Одним из методов активизации самостоятельности, инициативы и любознательности студентовмузыкантов выделяется творческая активность как высокий уровень познавательной активности. В статье отмечается, что каждый студент, кроме овладения методическими рекомендациями, профессиональными знаниями и умениями, вокальными, инструментальными и дирижерскими навыками, имеет возможность выстраивать собственную концепцию урока, определять свою позицию в рассматриваемом вопросе, использовать различные методические приемы, разрабатывать творческие задания, самостоятельно находить решение проблем, связанных с дисциплиной, восприятием информации учениками, созданием эмоционального климата на уроке. Таким образом, цель педагогической практики - закрепление и углубление знаний, полученных студентами в процессе обучения, а также приобретение опыта организационно-творческой работы на основе индивидуальноориентированного и проекционно-поискового подходов. Педагогическая практика выполняет ряд функций, среди которых: адаптационная, учебная, воспитательная, развивающая, формирующая, диагностическая. На основе педагогического наблюдения автор статьи делает вывод, что основными факторами, которые мешают проявлению творческой активности студентов в процессе самоподготовки к педагогической практике, является неуверенность студента, приверженность определенным схемам, установка на заданный способ организации учебно-воспитательного процесса. Одним из важнейших условий совершенствования профессиональной подготовки высококвалифицированных кадров является «ориентация на индивидуальное развитие будущего учителя». Решающим фактором субъективного порядка может стать творческое саморазвитие личности.

Ключевые слова: творческая деятельность, познавательная активность, студенты-музыканты, самоподготовка, педагогическая практика.

Рецензент: д. пед. н., проф. О. С. Реброва

Подано до редакичї 08.04.2016 